\title{
Value-Semantic Bases of Ideas About the Profession and Satisfaction With the Profession of Higher School Teachers
}

\author{
Vlada I. Pishchik ${ }^{*}$
}

\author{
${ }^{1}$ Don State Technical University, Russian Federation, e-mail: vladaph@yandex.ru
}

\begin{abstract}
The business culture in the educational system remains conservative, despite the fact that the values of tolerance are wide-spread in the world. This affects the transformation of ideas about the profession of teachers. The article establishes the relationship of ideas about the profession and satisfaction with the profession with the values and meanings of university teachers. It is assumed that in modern conditions of higher education, values and life meanings may differ among teachers with different ideas about the profession. The study sample consists of 270 university teachers aged between 25 and 65 years, work experience from 3 to 25 years, 150 women and 120 men. We used the questionnaire of professional satisfaction (Kissel), the method of measuring values (Schwartz), the semantic differential (Osgood), and the method of identifying life meanings (Kotlyakov). We defined groups of teachers with a neutral view and a positive view of the profession, with varying degrees of satisfaction with the profession. As a result, it was found out that the group of teachers with a neutral attitude to their profession has the most manifested values: conformity, hedonism, security, and meanings: hedonistic, status, and family. The group of teachers with a positive view of the profession, has the values of independence, achievement and security, combined with the meanings: altruistic, self-realization, family and cognitive. It is concluded that university teachers with positive ideas about the profession are more altruistic about their activities, and teachers with neutral ideas about the profession are pragmatic about it.
\end{abstract}

Keywords: ideas about the profession, satisfaction with the profession, teachers, values, life meanings, semantic space.

\section{Introduction}

Educational, methodological, bringing-up and scientific activities of higher school teachers require costant updating of personal resources in situations of market and state pressure (Panev and Barakoska, 2015; Kekeeva and Sherayzina, 2016; Dart, McCall, Ash, Blair and Palermo, 2019) and high accountability (Sambell, Brown and Graham, 2017). The main requirements for a university teacher in the modern conditions of education increase the relevance of the study of his value-semantic sphere in connection with changing ideas about the profession.

The ideas about the profession are a cognitive component of the image of the profession, interconnected with the motivational and value component.

In psychology, an idea (representation) is understood as a visual image of an object or phenomenon that arises from a personal experience by reproducing it in memory or in imagination. Social ideas are a generalizing symbol, a system of interpretation, classification of phenomena (Moscovici, 1990). Cognition and behavior exist only because they mean something in our ideas, notes Moscovici (1990). Ideas about the profession as a kind of social ideas determine the significance of the profession for a person.

Propositional representations and situational representations play an important role in the formation of ideas about the profession (Clarà, 2014). The situation largely corrects the teacher's knowledge and his attitude to work. Sometimes teachers ' mental representations of relationships with students shape their affective responses (Evans, D., Butterworth, G. and Law, 2019).

Representations of professionals as regulators of professional activity of self-determination have been studied by many researchers (Belova, 2014; Duţă, Pânişoară and Pânişoară, 2014; Belousov et all., 2015; Lyukshina and Kalita, 2018, etc.).

The authors note that adequate ideas about the profession among specialists are a condition for coscious compliance with the chosen professional activity and the direction of the personality as a whole. During the course of professional activity, a specialist asks questions about the correctness of the choice

${ }^{*}$ Corresponding author: vladaph@yandex.ru 
of profession, especially during crisis periods of professional development. The ideas about the profession strengthen or destroy the positive image of the profession (Belousov et all., 2015; Dart et al., 2019).

Professionals who evaluate their profession as a way of life have a specific perception of the surrounding world. In this case, the image of the profession and its ideas are perceived as natural, merged with the worldview of the professional (Lyukshina and Kalita, 2018).

The image of the profession is based not only on the realities of the profession, but also on the personal items, values that the specialist accepts. Professional representations are constructed on the bases on values, priorities, and guidelines. The system of value orientations is related to the highest goals of the individual (Pryazhnikov, 2014; Nevgi and Lofstrom, 2015). The highest goals of a professional are assocated with limited meanings.

Values and meanings determine the orientation of a professional's personality. In our research, we adered to the concepts of values by Schwartz (2006), which are universal and reflect the value foundations of the personality in a changing world and are interpreted as "known" needs, largely dictated by society and culture. Today, value oppositions that influence the formation of professional behavior are of great interest (Golyanich et all., 2018). According to a study of teachers in Nigeria, it was found out that male teachers had lower average scores in the "taking care of themselves" and "taking care of business" than women. The higher the years of work, the lower their "taking care of the family" (Chinweuba et all., 2019).

We were interested in values that are most expressed among university teachers. There are not many studies devoted to studying the values of higher school teachers, and they primarily emphasize the instrumentality of teachers' values. The values of teachers in the works of authors are such values as goals, means, norms, and regulators of pedagogical activity.

Values, regulating pedagogical activity, are interconnected with meanings. "Semantic-forming motives" act as motivators of activity. They also give it a personality meaning (Leontiev, 2005). Understanding peagogical activity, in interaction with colleagues and students, teachers generate new meanings. We would like to understand exactly what meanings are interlinked with what values among university teacers today.

Professional activity is guided by instrumental meanings that are included in the professional's life meaings (Koteneva and Kobzarev, 2019). The teaching profession can be associated in different ways with the leaing meanings of a teacher's life: the profession of a teacher as the main meaning of his life; the profession of a teacher as an instrumental meaning of his life; the profession as not the most significant element of the meaning of his life (Belousov et al., 2015). The semantic content of a teacher's professional activity is significant for its realization.

Logically, we can conclude that meanings guide values. In the process of development of a specialist, during which there is a change of roles, positions, new motives are born, which affects his views and image of the profession. One of the functions of representation is to convey meaning (Moscovici, 1990). Consequently, as a result, it becomes clear that the system of representations generates meanings, which in turn stimulate or strengthen the values of the professional.

Values, meanings and ideas about the profession give rise to a special attitude to it. The attitude to the profession determines the professionalism of a teacher. There are 4 types of attitude to the profession: profession as a hobby; profession as a vocation; profession as a disappointment; alienation in the profession (Peretyatko, 1991). These relationships may be the sides of the overall attitude to one's profession at various stages of becoming a professional. In crisis situations, a teacher may also face alienation from the profession and experience frustration. However, in moments of success, the teacher may feel a passion for professional activities and see the profession as his vocation. Professional skills include a set of core values or fundamental elements in addition to mastering the broad scientific knowledge and skills of the profession, and these are aspects of humanism. Professionalism is a multidimensional concept that includes core values or humanistic aspects such as respect, responsibility, care, leadership, altruism, compassion, etc. (Salam et al., 2012).

The basic understanding of the meaning of work is closely related to the spiritual values that people possess in their work. They help to increase job satisfaction and self-fulfillment in work through internal and external satisfaction, to be able to increase productivity and well-being satisfaction. Workplace spirituality also has a positive and meaningful relationship with organizational commitments (Fanggidae et al., 2016).

In the course of professional development, the image of the profession and its ideas change, it is filled with new content or distorted (Ovsyannikova, 1981; Panev and Barakoska, 2015; Kekeeva and Sherayzina, 2016). This is largely influenced by working conditions, interaction in the work team, the degree of job satisfaction, and so on. That is, the degree of subjective well-being of a specialist at work largely influences the views and image of the profession. Teachers who have a strong personal professional orientation, in which they show liberal views of higher education and the importance of 
research, the learning process, internal value for themselves, and a strong professional commitment to teaching express their position by the statement that if it were not for students, he would not have stayed at the university (Dunning, 2019).

The values and meanings of modern teachers appeared in the era of socialism or the transitional era of perestroika. The past era assumed traditional values of collectivism. These values were based on a stable way of life and peace. The meanings of the teaching profession were related to the service of the public well-being, the goal was to educate and develop a harmonious personality. New realities in the educational space have changed. The teaching process is based on the competence model of a specialist. The control over the activity of teachers has increased as well as the number of submitted work reports. Educational goals have disappeared from the law on education. The values and meanings of the profession of a teacher from the socialism era are in conflict with the modern requirements. Generalization of research in this area allowed us to formulate the following contradictions between the expectations of the profession, ideas about their profession of teachers and the presence of a sense of impossibility to implement these expectations and ideas.

This is the problem of research, namely, the identification of value-semantic bases of ideas about the profession and satisfaction with it among higher school teachers. Thus, based on the above mentioned, we formulated the purpose of the study: to study the values and meanings of university teachers with different ideas about their profession.

\section{Materials and methods}

The study sample consisted of university teachers from Rostov-on-Don in the number of 270 people, aged between 25 and 65 years $(M=32$; $S O=7.6)$, work experience from 3 to 40 years, 150 women and 120 men, teachers of humanitarian specialties and directions. All teachers participated in the survey voluntarily.

The study used: professional satisfaction questionnaire (A. A. Kissel) (Yadov and Kissel, 1974); Values questionnaire (Schwartz, 2006) (adapted by Karandashev, 2004); Method of determining Kotlyakov's life meanings (2004); Semantic differential (Osgood, 1959). Statistical methods: correlation analysis, Mann-Whitney difference criterion, exploratory factor analysis (Principal Components Analysis).

The questionnaire "Attitude to the profession" by A. Kissel (Yadov and Kissel, 1974). The questionnaire is a survey that was conducted in writing. The questionnaire presents 15 statements, which the survey participants should note if they agree with it. The method of presenting answer options is dichotomous. Three statements each relate to different levels of satisfaction with the profession. The satisfaction index consists of 5 responses. If the respondent is fully satisfied with the profession, he gets 5 points if he is satisfied in general, gets 4 points, if he is undefined, then he gets 3 points, if he is satisfied a little, then he gets 2 points and if he is not satisfied, then he gets 1 point.

The semantic differential technique by Osgood (Osgood, 1959). This is a method of quantitative and qualitative assessment of objects and subjects by means of a two-pole scale. The method reveals associative connections between objects in consciousness. Traditionally, the author has defined 16 scales. Each scale is represented by a pair of antonyms that express the desired parameter. This technique explores the subjective space of a person. Each scale contains a gradation from -3 to +3 . According to Osgood, 1959 each parameter can be attributed to 3 factors: score, strength, and activity. The rating for the group is carried out on each scale, and the average indicator is calculated. The results can also be represented as a space where the concepts under study (points in space) and the distances between them are indicated, which can indicate their semantic load.

The method of Schwartz, 2006 allowed us to investigate the value orientation of teachers. In our work, we used the Schwartz method, 2006 for the study of personal values, since the second method is used for the study of cultural values. The methodology is a structured questionnaire. It contains statements of agreement or disagreement that the respondent must express. The method described was adapted for the Russian respondents. The method presents 10 values that were different in motivational orientation (power, achievement, hedonism, stimulation, independence, universalism, kindness, tradition, conformity, security). In the questionnaire, the subject evaluates the importance of the value from 1 to 7 points. Then the average value is calculated for each value and the significance of the value for the respondent is determined. The very first ranks are occupied by values that are the most important ones for the individual.

The Kotlyakov's method of determining life meanings (2004). The method is aimed at identifying the hierarchy of life meanings in respondents. The author, studying various methods, definitions of meanings, identified 8 categories of life meanings: altruistic, existential, hedonistic, status, communicative, family, cognitive, self-realization. The author understands the presented meanings as follows: 
- altruistic - based on the need to help others selflessly;

- existential - based on the need for freedom of choice, filled with living a life;

- hedonistic - based on the need to enjoy the full benefits of life;

- status - based on the need to build a career, achieve status heights in life;

- communicative - based on the need to communicate with others, to experience the pleasure of communicating with others;

- family - based on the need to take care of your family, the need to build positive relationships in the family;

- cognitive - based on the need to know the surrounding world, to identify the essence of phenomena;

- self-realization - based on the human need for self-development and self-improvement.

The subject selects the most significant statements out of 24 , which are then divided into categories. Then the rank values for each category are calculated.

We put forward the following hypothesis: $\mathrm{H1}$ - it is possible to identify groups of teachers with a different attitude to the profession; $\mathrm{H} 2$ - it is possible to define the difference of the semantic elements of views about the profession of teachers with different attitude to the profession; $\mathrm{H} 3$ - we assume that values will be significantly different among the teachers with different attitude to the profession; $\mathrm{H} 4$ - we assume that life meanings will be significantly different among the teachers with different attitude to the profession; $\mathrm{H} 5$ - we assume that it is possible to reveal the relationship between indicators in the studied groups.

\section{Results}

To differentiate groups of teachers, we used the Kissel job satisfaction questionnaire (Yadov and Kissel, 1974). It includes statements that reflect the attitude to the profession. Since satisfaction with the profession, which expresses an attitude to the profession is associated with the idea of it, we can use this questionnaire.

The results of the questionnaire are shown in Fig.1 and 2.

Out of $64,81 \%$ of the teachers - 175 people - are "generally" satisfied with the profession and we put them in Group 1, which we called the "positive ides of the profession" group (Fig.1). In their responses, the teachers of this group highlighted the following statements:

"I like my profession more than I don't like it";

"I believe that my profession is no worse than many others";

"Most other professions are better than my profession".

We would like to note that the teachers mentioned in their comments other professions that may be better. The teachers particularly noted the professions with high earnings. The teachers also referred to the crisis in the educational system and called for radical changes.

\section{Figure 1.}

Professional satisfaction in a group of teachers with a positive idea of the profession

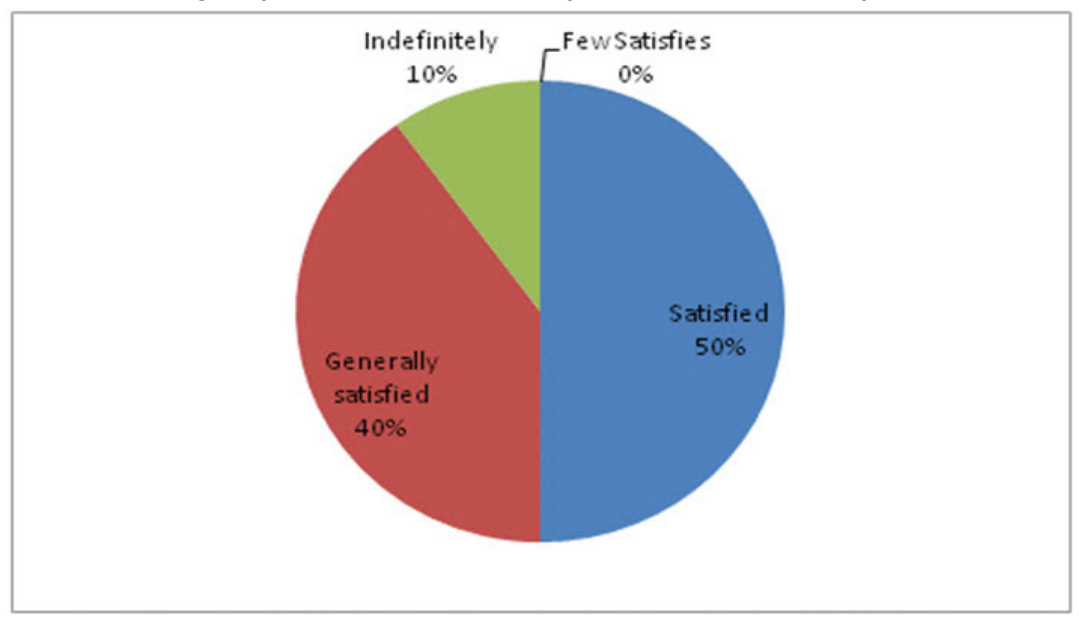

As a result of the research out of 270 teachers, $35.19 \%$ - 95 people answered that they had an undefined attitude to the profession, and we assigned them to Group 2, which was called the "neutral idea of the profession" group (Fig.2). These teachers marked the following positions in the questionnaire:

"My profession is not worse or better than others"; 
"It's hard to say whether I like my profession";

"I am quite indifferent to my profession."

Almost all teachers of this group noted in their comments that this attitude to the profession is generated by the current situation in education, which they described as a crisis. Some teachers also noted that they probably have professional burnout. They said that it is unlikely that something can be changed here and it is better to keep neutrality.

\section{Figure 2.}

Professional satisfaction in a group of teachers with a neutral idea of the profession

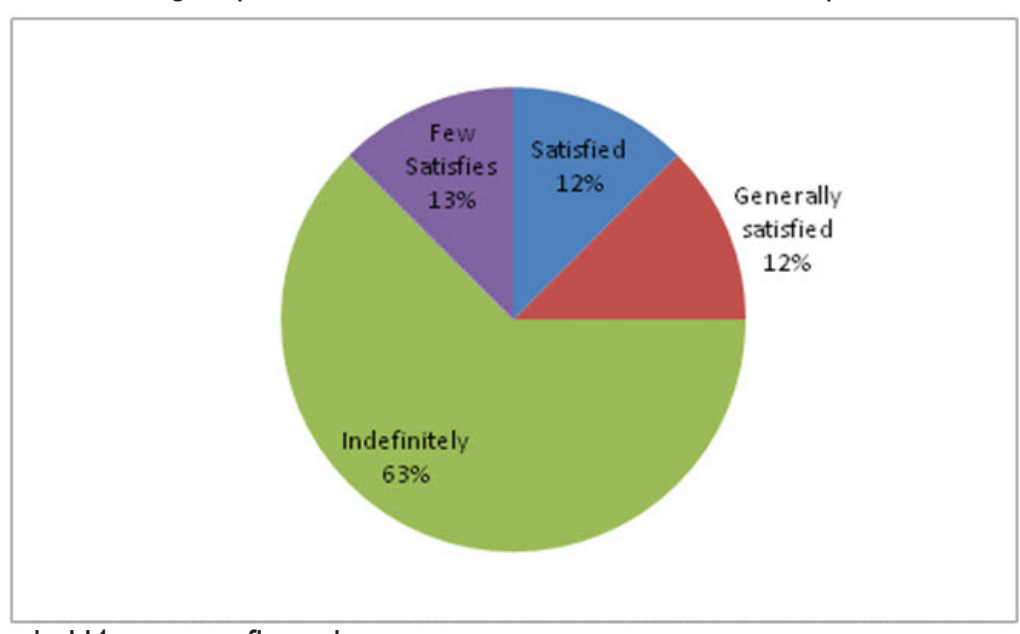

The hypothesis $\mathrm{H} 1$ was confirmed

To confirm the result, it was necessary to support the indicators of attitude to the profession with the data on the semantics of ideas about the profession. We performed a semantic differential method in two groups. The results are shown in Table 1.

Table 1.

Indicators of the semantic differential of ideas about the profession in two groups of teachers

\begin{tabular}{|c|c|c|c|c|c|c|c|c|c|c|c|c|}
\hline \multicolumn{13}{|c|}{ Descriptive Statistics } \\
\hline \multirow[b]{2}{*}{ Indicators } & \multicolumn{2}{|c|}{$\mathrm{N}$} & \multicolumn{2}{|c|}{ Minimum } & \multicolumn{2}{|c|}{ Maximum } & \multicolumn{2}{|c|}{ Mean } & \multicolumn{2}{|c|}{ Std. Deviation } & \multirow[t]{2}{*}{$\mathrm{U}$} & \multirow[t]{2}{*}{$P$} \\
\hline & $\mathrm{Ne}$ & Po & $\mathrm{Ne}$ & Po & $\mathrm{Ne}$ & Po & $\mathrm{Ne}$ & Po & $\mathrm{Ne}$ & Po & & \\
\hline Jolly & 95 & 175 & 19,00 & 26,00 & 21,00 & 30,00 & 20,2143 & 28,0000 &, 57893 & 1,45095 & 231 & 0,00 \\
\hline Good & 95 & 175 & 12,00 & 25,00 & 14,00 & 27,00 & 13,3571 & 26,5000 & ,74495 & 68825 & 631 & 0,00 \\
\hline Full & 95 & 175 & 14,00 & 20,00 & 16,00 & 23,00 & 15,0714 & 21,7000 &, 73005 & 92338 & 52 & 0,013 \\
\hline Light & 95 & 175 & 12,00 & 12,00 & 15,00 & 14,00 & 13,9286 & 13,1000 &, 73005 & 85224 & 552 & 0,001 \\
\hline New & 95 & 175 & 22,00 & 23,00 & 24,00 & 25,00 & 22,7857 & 24,3000 &, 69929 & 80131 & 43 & 0,00 \\
\hline Quick & 95 & 175 & 23,00 & 23,00 & 25,00 & 27,00 & 24,6429 & 25,9000 &, 63332 & 1,55259 & 613 & 0,007 \\
\hline Warm & 95 & 175 & 11,00 & 12,00 & 13,00 & 14,00 & 12,0714 & 13,0000 &, 73005 & 64889 & 72 & 0,00 \\
\hline Long & 95 & 175 & 18,00 & 25,00 & 21,00 & 27,00 & 19,7857 & 26,3000 & 80178 & 80131 & 433 & 0,017 \\
\hline Complex & 95 & 175 & 19,00 & 23,00 & 21,00 & 26,00 & 19,8571 & 24,4000 & 66299 & ,94032 & 224 & 0,012 \\
\hline Active & 95 & 175 & 23,00 & 25,00 & 26,00 & 29,00 & 24,5000 & 27,7000 &, 75955 & 1,03110 & 570 & 0,05 \\
\hline Strong & 95 & 175 & 9,00 & 10,00 & 11,00 & 14,00 & 12,2857 & 10,9000 &, 61125 & 1,07115 & 517 & 0,00 \\
\hline large & 95 & 175 & 27,00 & 21,00 & 28,00 & 24,00 & 27,4286 & 22,4000 &, 51355 & ,94032 & 420 & 0,00 \\
\hline Valid N (listwise) & 95 & 175 & & & & & & & & & & \\
\hline
\end{tabular}

Po - a positive view of the profession

$\mathrm{Ne}$ - a neutral view of the profession

All the scales showed the significance in differences in the groups. Teachers with a positive view of the profession dominated on the following scales: quick, warm, new, difficult, long, light, full, good and cheerful. Table 1 shows the significance of the differences. As we can see from the results of the obtained 
data (Table 1), teachers with a positive view of the profession and a neutral view of the profession rated activity in the profession equally, but had significant differences in the activity indicator $(U=0.570 ; p=0.05)$. From the side of rapidly changing conditions in higher education, mobility and from the point of view of novelty, teachers need to be active. To a lesser extent, teachers appreciated the warmth of relationships at work, the bright sides of the profession and the strength of the profession. There was a domination of negative responses. This indicates that it is not possible to receive psychological support from colleagues in difficult working conditions.

Next, we obtained a spatial representation of the semantic space values of the profession representation. To do this, the data was factorized. The results are presented in Tables 2 and 3 . for the groups with positive ideas of the profession. The 4 components presented accounted for $84.485 \%$ of the dispersion.

Table 2.

Total Variance Explained for Group 1

\begin{tabular}{|c|c|c|c|c|c|c|}
\hline \multicolumn{7}{|c|}{ Total Variance Explained } \\
\hline \multirow[b]{2}{*}{ Component } & \multicolumn{3}{|c|}{ Initial Eigenvalues } & \multicolumn{3}{|c|}{ Extraction Sums of Squared Loadings } \\
\hline & Total & $\%$ of Variance & Cumulative $\%$ & Total & $\%$ of Variance & Cumulative $\%$ \\
\hline 1 & 4,096 & 34,130 & 34,130 & 4,096 & 34,130 & 34,130 \\
\hline 2 & 2,509 & 20,909 & 55,039 & 2,509 & 20,909 & 55,039 \\
\hline 3 & 2,353 & 19,606 & 74,645 & 2,353 & 19,606 & 74,645 \\
\hline 4 & 1,181 & 9,840 & 84,485 & 1,181 & 9,840 & 84,485 \\
\hline 5 & ,761 & 6,340 & 90,825 & & & \\
\hline 6 &, 504 & 4,196 & 95,021 & & & \\
\hline 7 & ,287 & 2,391 & 97,412 & & & \\
\hline 8 & ,226 & 1,884 & 99,296 & & & \\
\hline 9 & 085 &, 704 & 100,000 & & & \\
\hline 10 & $1,184 \mathrm{E}-15$ & $9,869 \mathrm{E}-15$ & 100,000 & & & \\
\hline 11 & $1,384 \mathrm{E}-16$ & 1,153E-15 & 100,000 & & & \\
\hline 12 & $7,903 \mathrm{E}-17$ & $6,586 \mathrm{E}-16$ & 100,000 & & & \\
\hline
\end{tabular}

\section{Table 3.}

Component matrix for Group 1

\begin{tabular}{|c|c|c|c|c|}
\hline \multicolumn{5}{|c|}{ Component Matrix ${ }^{a}$} \\
\hline & \multicolumn{4}{|c|}{ Component } \\
\hline & 1 & 2 & 3 & 4 \\
\hline Cheerful & ,769 & , 131 &, 305 &, 115 \\
\hline Good &,- 793 &, 528 & , 106 &,- 020 \\
\hline Fast & ,643 & ,497 &,- 532 &,- 056 \\
\hline Activity & ,588 & ,392 &,- 515 & ,285 \\
\hline Warm &,- 834 & 022 & ,393 &,- 146 \\
\hline Full & ,796 & ,218 & ,393 &,- 075 \\
\hline New &,- 059 &,- 600 &,- 398 &, 526 \\
\hline Long & ,239 &,- 718 &,- 240 &,- 352 \\
\hline Complex &,- 005 & ,878 &,- 122 &,- 205 \\
\hline Strong & ,234 &, 042 &, 878 &, 013 \\
\hline Big & ,632 &,- 154 &, 617 & ,301 \\
\hline Light &,- 522 & ,308 & , 100 &, 722 \\
\hline $\begin{array}{l}\text { Extraction } \\
\text { a. } 4 \text { comp }\end{array}$ & $\begin{array}{l}\text { d: Princi } \\
\text { extracte }\end{array}$ & mpone & nalysis. & \\
\hline
\end{tabular}


The semantic spaces of profession representations in groups are shown in Fig. 3 and 4.

\section{Figure 3.}

Spatial representation of semantic space values ideas of the profession of teachers with positive views of the profession

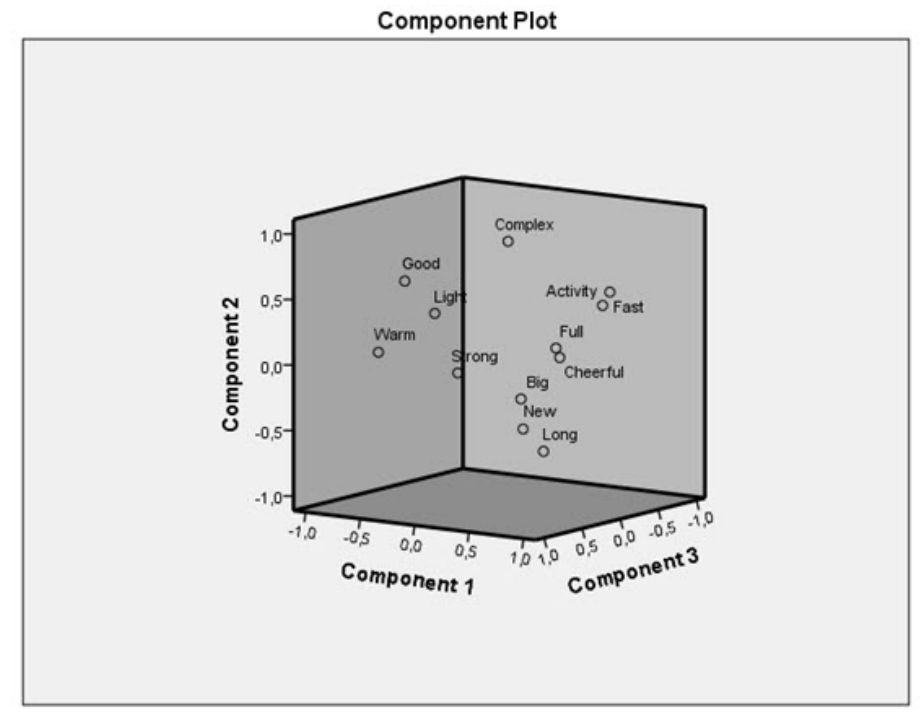

As you can see in Figure 3, the space can be divided into three areas of represented semantics in a group with positive ideas about the profession. In the first area, we can distinguish four concepts: warm, good, light and a little strong, which indicates a positive background for the profession. The second space combines the following concepts: active, fast, full, and fun. We think that this reflects the dynamic part of the idea of the teaching profession. The third space grouped the concepts: big, new, long, which is opposed by the indicator complex. It is possible that this opens up the introduction of various innovations into the work of university teachers.

Factorization of data in a group with neutral views of the profession. The results are presented in Tables 4 and 5 for the groups with neutral views of the profession. The 5 components presented made up $86.188 \%$ of the dispersion.

\section{Table 4.}

Total Variance Explained for Group 2

\begin{tabular}{|c|c|c|c|c|c|c|}
\hline \multicolumn{7}{|c|}{ Total Variance Explained } \\
\hline & \multicolumn{3}{|c|}{ Initial Eigenvalues } & \multicolumn{3}{|c|}{ Extraction Sums of Squared Loadings } \\
\hline & & & & & & Cumulative \\
\hline Component & Total & $\%$ of Variance & Cumulative \% & Total & $\%$ of Variance & $\%$ \\
\hline 1 & 3,405 & 28,371 & 28,371 & 3,405 & 28,371 & 28,371 \\
\hline 2 & 2,256 & 18,800 & 47,171 & 2,256 & 18,800 & 47,171 \\
\hline 3 & 2,077 & 17,308 & 64,479 & 2,077 & 17,308 & 64,479 \\
\hline 4 & 1,475 & 12,291 & 76,770 & 1,475 & 12,291 & 76,770 \\
\hline 5 & 1,130 & 9,418 & 86,188 & 1,130 & 9,418 & 86,188 \\
\hline 6 &, 593 & 4,945 & 91,133 & & & \\
\hline 7 & 408 & 3,403 & 94,537 & & & \\
\hline 8 & ,293 & 2,442 & 96,979 & & & \\
\hline 9 & ,231 & 1,927 & 98,906 & & & \\
\hline 10 & 079 & ,659 & 99,565 & & & \\
\hline 11 & ,036 & ,301 & 99,865 & & & \\
\hline 12 &, 016 & , 135 & 100,000 & & & \\
\hline
\end{tabular}


Table 5.

Component matrix for Group 2

\begin{tabular}{|c|c|c|c|c|c|}
\hline \multicolumn{6}{|c|}{ Component Matrix } \\
\hline & \multicolumn{5}{|c|}{ Component } \\
\hline & 1 & 2 & 3 & 4 & 5 \\
\hline Sad &,- 672 &,- 069 & 623 & 095 & 203 \\
\hline Bad & ,449 & 198 &, 516 &, 564 &,- 292 \\
\hline Fast &, 537 &, 085 &, 660 &,- 038 & ,236 \\
\hline Activity & ,832 &,- 036 &,- 345 & ,290 &,- 113 \\
\hline Cool & ,328 &,- 330 & 219 & ,408 &, 732 \\
\hline Full &,- 411 &, 742 &,- 184 & , 165 & ,260 \\
\hline New &,- 198 &,- 875 &,- 063 & , 101 & ,153 \\
\hline Long &,- 036 & 613 &, 588 &,- 393 & 037 \\
\hline Complex & ,420 & ,480 &,- 494 &,- 121 &, 516 \\
\hline Strong &,- 805 &,- 221 &,- 035 &,- 249 & , 155 \\
\hline Big &,- 553 & 167 & 135 & 629 &,- 120 \\
\hline Dark &, 567 &,- 309 & ,415 &,- 480 &,- 045 \\
\hline
\end{tabular}

Extraction Method: Principal Component Analysis.

a. 5 components extracted.

Figure 4.

Spatial representation of semantic space values ideas of the profession of teachers with neutral views of the profession

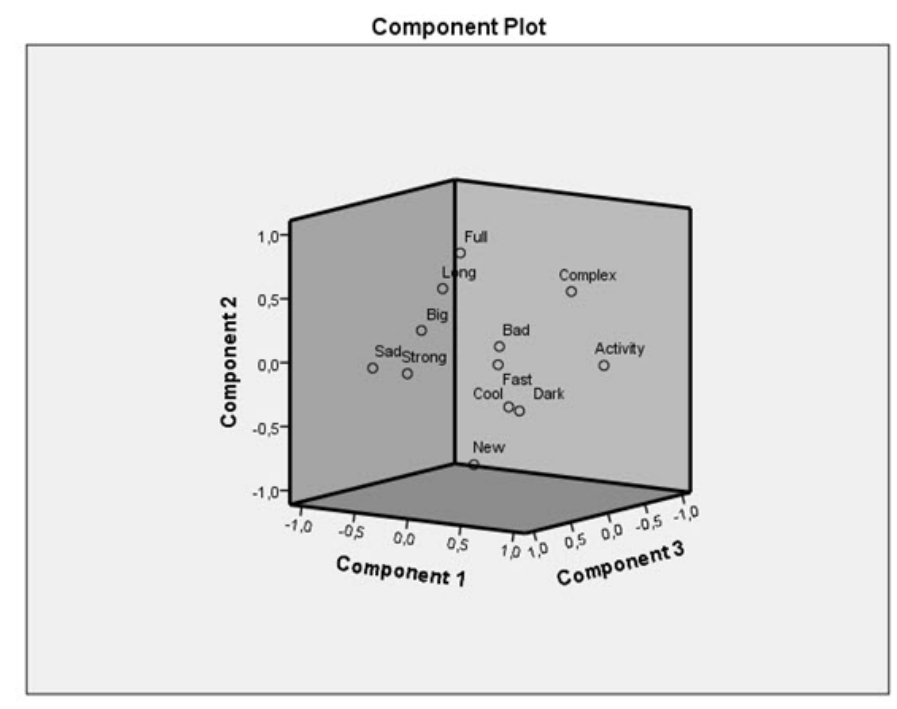

As you can see in Figure 4, the space can be divided into the following areas of represented semantics in a group with neutral ideas about the profession. In the first area, you can find the concepts: new, cold, dark, which indicates a negative background for the representation of the profession. The second space combines the concepts: complex, bad, fast, active. We think that this reflects the dynamic part of the idea of the teaching profession. The third space grouped the concepts: full, long, large. Here we see the meaning of the profession as filled. The fourth space is sad and strong.

Having applied the Mann-Whitney difference criterion (Table 1), it could be concluded that teachers with a positive view of the profession rated the profession as more complex $(U=63 ; p=0.012)$, lasting a long time $(U=.433 ; p=0.017)$, filled $(U=52 ; p=0.013)$, good and fun $(U=613 ; p=0.000)$.

The teachers with a neutral view of the profession rated the profession as strong $(U=517 ; p=0.000)$. So, the $\mathrm{H} 2$ hypothesis was confirmed.

Next, we explored the values of teachers. The results are shown in Table 6. 
Table 6.

The expression of values in two groups of teachers

\begin{tabular}{lrrrrrrrrrrrrrr}
\hline \multicolumn{10}{c}{ Maximum } & \multicolumn{1}{c}{ Mean } & \multicolumn{1}{c}{ Std. Deviation } \\
\hline \multicolumn{1}{c}{} & \multicolumn{1}{c}{$\mathrm{N}$} & \multicolumn{1}{c}{ Minimum } & \multicolumn{1}{c}{ Mescriptive Statistics } \\
\hline Indicators & $\mathrm{Ne}$ & $\mathrm{Po}$ & $\mathrm{Ne}$ & $\mathrm{Po}$ & $\mathrm{Ne}$ & $\mathrm{Po}$ & $\mathrm{Ne}$ & $\mathrm{Po}$ & $\mathrm{Ne}$ & $\mathrm{Po}$ & $\mathrm{U}$ & $\mathrm{P}$ \\
\hline Safety & 95 & 175 & 4,9 & 4,1 & 5,1 & 4,4 & 5 & 4,2273 & 0,06325 & 0,1009 & 621 & 0,00 \\
Conformity & 95 & 175 & 3,4 & 5 & 4,1 & 5,3 & 3,7455 & 5,1364 & 0,18091 & 0,0809 & 147 & 0,013 \\
Traditions & 95 & 175 & 4 & 3,8 & 4,6 & 4,1 & 4,2182 & 3,9818 & 0,17787 & 0,08739 & 432 & 0,78 \\
Compassion & 95 & 175 & 4,1 & 3,8 & 4,3 & 4,1 & 4,1636 & 3,9818 & 0,0809 & 0,07508 & 340 & 0,65 \\
Universalism & 95 & 175 & 3,5 & 2,9 & 3,9 & 3,1 & 3,8091 & 3 & 0,13751 & 0,06325 & 221 & 0,77 \\
Independence & 95 & 175 & 4,3 & 3,1 & 4,7 & 4 & 4,5091 & 3,3818 & 0,1446 & 0,23587 & 521 & 0,015 \\
Stimulation & 95 & 175 & 3,2 & 2 & 3,7 & 2,4 & 3,4636 & 2,2182 & 0,15015 & 0,1328 & 737 & 0,00 \\
Hedonism & 95 & 175 & 2 & 4 & 2,4 & 4,3 & 2,1273 & 4,0909 & 0,11909 & 0,10445 & 432 & 0,018 \\
Power & 95 & 175 & 2,5 & 3,1 & 3 & 3,6 & 2,8182 & 3,3636 & 0,16011 & 0,15667 & 446 & 0,84 \\
Achievements & 95 & 175 & 4,1 & 3,1 & 4,8 & 3,3 & 4,4182 & 3,1818 & 0,1834 & 0,07508 & 503 & 0,010 \\
Valid N (listwise) & 95 & 175 & & & & & & & & & & \\
\hline
\end{tabular}

As the results of the study of values show (Table 6), teachers with a neutral view of the profession have the most expressed values: safety, conformity, hedonism. Consequently, they strive for stability in relationships, to meet the expectations of others are aimed at enjoying the work they do.

In the group of teachers with positive ideas about the profession, the following values are more expressed: safety, achievement, independence. Therefore, these teachers are also aimed at stability in relationships at work, are focused on success, independent decision-making about the choice of ways to act at work.

We found significant differences on the scales of conformity $(U=147 ; p=0.013)$, hedonism $(U=432$; $p=0.078$ ) with the predominance of a group of teachers with a neutral view of the profession. The scales of safety $(U=621 ; p=0.000)$, achievement $(U=503 ; p=0.010)$, stimulation $(U=737 ; p=0.000)$ and independence $(U=521 ; p=0.015)$ with the predominance of a group of teachers with a positive view of the profession.

By including values in the professional orientation, we can conclude that the teachers with a neutral view of the profession expressed conservatism, self-exaltation. Teachers with a neutral view of the profession are aimed at conservatism, self-realization through achievement and openness to experience.

Both groups of teachers noted the value of security, which reflects their vision of the educational system as a crisis. The H3 hypothesis was confirmed.

Next, we conducted a study of life meanings in two groups. The results are shown in Table 7.

Table 7.

The expression of life meanings among the teachers

\begin{tabular}{|c|c|c|c|c|c|c|c|c|c|c|c|c|}
\hline \multicolumn{13}{|c|}{ Descriptive Statistics } \\
\hline & \multicolumn{2}{|c|}{$\mathrm{N}$} & \multicolumn{2}{|c|}{ Minimum } & \multicolumn{2}{|c|}{ Maximum } & \multicolumn{2}{|c|}{ Mean } & \multicolumn{2}{|c|}{ Std. Deviation } & \multirow[b]{2}{*}{ U } & \multirow[b]{2}{*}{$P$} \\
\hline Life meanings & $\mathrm{Ne}$ & Po & $\mathrm{Ne}$ & Po & $\mathrm{Ne}$ & Po & $\mathrm{Ne}$ & Po & $\mathrm{Ne}$ & Po & & \\
\hline Altruistic & 95 & 175 & 2,1 & 3,54 & 2,34 & 3,8 & 13,1 & 24,2 & 0,14709 & 0,19936 & 156 & 0,02 \\
\hline Existential & 95 & 175 & 3,1 & 3,95 & 3,14 & 4 & 15 & 20,9 & 0,01027 & 0,01494 & 657 & 0,76 \\
\hline Hedonistic & 95 & 175 & 3,42 & 4,5 & 3,48 & 4,52 & 25 & 15,1 & 0,01789 & 0,00707 & 293 & 0,00 \\
\hline Self-realization & 95 & 175 & 2,2 & 3,54 & 2,34 & 4 & 22 & 23,8 & 0,0388 & 0,11723 & 541 & 0,83 \\
\hline Status & 95 & 175 & 4,1 & 2,11 & 4,3 & 2,2 & 24,2 & 22,3 & 0,06325 & 0,02421 & 474 & 0,66 \\
\hline Communicative & 95 & 175 & 3,21 & 4,4 & 3,45 & 4,58 & 21,3 & 20,8 & 0,06369 & 0,04718 & 507 & 0,83 \\
\hline Family & 95 & 175 & 3,3 & 2,3 & 3,8 & 2,9 & 24,18 & 25,4 & 0,14709 & 0,19936 & 649 & 0,64 \\
\hline Cognitive & 95 & 175 & 3 & 4,89 & 4,4 & 5 & 22,09 & 22,5 & 0,40233 & 0,03013 & 172 & 0,012 \\
\hline Valid N (listwise) & 95 & 175 & & & & & & & & & & \\
\hline
\end{tabular}


In the group of teachers with a positive view of the profession, the following life meanings are most expressed: altruistic, existential, family, and cognitive. In the group of teachers with a neutral view of the profession, the following life meanings are most expressed: hedonistic, status, and family.

The greatest differences between the two groups were altruistic life meanings $(U=156 ; p=0.020)$, hedonistic $(U=293 ; p=0.000)$, and cognitive $(U=172 ; p=0.012)$. The $H 4$ hypothesis was confirmed.

Our attention was drawn to the result showing that the group of teachers with a positive attitude to the profession has the least hedonistic meanings, and the group of teachers with a neutral view of the profession has the least altruistic meanings. Thus, the teachers with a positive view of the profession are willing to sacrifice their personal time for work, and teachers with a neutral view of the profession are not ready to do this.

Next, we processed the data obtained by means of Pearson's correlation analysis. The correlation analysis actually combined the results of the obtained data in each group.

In the group of teachers with a positive view of the profession, the following correlations were established: between complexity and family meanings (correlation coefficient $r=0.50^{*}$ ); altruistic meanings and security $\left(r=0.70^{* *}\right)$; fullness and independence $\left(r=0.56^{*}\right)$; complexity and achievements $\left(r=0.62^{*}\right)$; cognitive meanings and complexity $\left(\mathrm{r}=0.53^{* *}\right)$.

In a group of teachers with a neutral view of their profession, the following correlations were found: between conformity and value hedonism $\left(r=0.53^{* *}\right)$; great strength and security $\left(r=0.54^{*}\right)$, status meanings $\left(r=0.63^{*}\right)$; hedonistic meanings and family values $\left(r=0.71^{*}\right)$. The $\mathrm{H} 5$ hypothesis was confirmed.

\section{Discussions}

The modern education system places high demands on high school teachers. Conditions have changed, and such phenomena as the expansion of information flows, the improvement of technical means, the acceleration of life, and changes in the nature of social relations are manifested. Therefore, it is important to study the psychological characteristics of high school teachers.

In our study, we established the features of values and meanings of university teachers with different ideas about their profession. However, we did not emphasize a specific area of professional activity, noting only that the studied teachers are humanitarians. In a study of the semantics of the image of the teaching profession in the field of linguistics (Belousov et al., 2015), it was noted that for professors, the domains were: intelligence, ethics, and emotionality. They were opposed by domains: materialism, hedonism. This is combined with our results on the altruism of teachers with a positive view of the profession.

We have shown that the concept of a profession includes the image of a profession, which is influenced by the attitude to the profession. Our data can be compared with the Turkish researchers (Erus, Cakmak and Celebi, 2015), who demonstrate that it is typical for university teachers to emphasize the main disadvantage of academicity is low income (42\%). Turkish teachers identified the advantage of their profession in the fact that they share scientific knowledge with young people (30\%) and the prestige of the profession in society (17\%).

Images of the profession are included in the professional self-determination of the specialist's personality. In the course of self-realization, the subjectivity of the teacher as a creative person is formed (Panov and Selezneva, 2019). There are 5 levels of self-realization in the profession: 1) destructive level of rejection of their profession, includes an aggressive component; 2) avoiding level - the desire to avoid professional activity; 3) passive level includes the performance of activities on a model; 4) perfect level, when a specialist seeks to improve his activities; 5) the creative level implies creativity in professional activity (Pryazhnikov, 2014). The presented levels helped us to classify university teachers into different categories according to their ideas about their profession in the empirical part of the study.

In our work, we have paid special attention to the issues of value and semantic sphere of a teacher, which guide his activities and largely determine the subjective well-being in the profession, affect the selfattitude of the teacher to himself as a specialist.

Our study of teachers' meanings can be compared with the study of the Romanian colleagues (Duţă et al., 2014). It was shown that the Romanian teachers have general competencies in the $1^{\text {st }}$ place, pedagogical competencies in the $2^{\text {nd }}$ place, and scientific competencies in the $3^{\text {rd }}$ place. The Spanish teachers ranked the teaching competence on the $1^{\text {st }}$ place, which were followed by scientific and general ones. In our study, cognitive, altruistic, and existential meanings were ranked first. It is important that existential meanings and values of safety have taken a significant place. It is also interesting from the point of view that it is in tune with the position of the Indian colleagues (Mahipalan and Sheena, 2019), who consider spirituality and subjective happiness to be a necessary component of teaching.

We have proved that teachers with different ideas about the profession differ in the expression of 
certain values and meanings. These were values and meanings in the group with positive ideas: altruistic, achievements, and in the group with neutral ideas - it was conformity and hedonism. We confirmed our results by a similar study (Abakumova, Berberyan and Berberyan, 2019). The teachers emphasized the value of safety, which reflects the current unstable working conditions. Our result is combined with the data of Ovchinnikov, Bogomaz, and Gychev (2015), Panev and Barakoska (2015), Kekeeva, Sherayzina (2016), which demonstrate that the structure of the profession's image has stable, sustainable, situational and changeable ideas.

\section{Conclusions}

In the study, we reproduced the semantics of high school teachers' ideas about their profession at the moment. We noted the importance of understanding the profession for a university teacher for greater meaning and awareness of being in the profession. We revealed the connection and interpenetration of ideas about the profession with the image of the profession. The semantics of ideas about the profession of a teacher can be considered an indicator of the image of the profession. Then we moved on to what motivates and guides a teacher, namely the values and meanings of the specialist profession. We considered values as an important concept of psychology that has a long tradition. We emphasized that the main approach that was the starting point for us was the Schwartz approach, which in the study of many countries identified 10 core values that are manifested in different cultures. They point to various aspects of a professional's life and reveal the main directions for the development of his personality.

For us, it was important that meanings guide values, and values influence ideas about the profession of specialists. As a result of the research, we were able to differentiate groups of teachers according to their ideas about their profession and attitudes. These were positive views and neutral ones. It should be noted that there were no teachers who would have rated the profession at the highest rank. Many teachers noted the negative aspects of modern higher education.

The teachers with a neutral attitude to the profession rated it more powerful, and teachers with a positive attitude to the profession rated it emotionally rich. Both groups noted activity in this profession.

In the group with positive ideas about the profession, the following value-semantic components were identified: the values of independence, achievement, security are combined with the life meanings of altruism, cognitive and family. This may indicate that it is important for teachers of this group to self-lessly serve their cause and achieve certain results.

In the group with a neutral attitude to the profession, teachers show the following features of the value-semantic sphere: conformity, hedonism and security are combined with the life meanings of hedonism, status and family. It is noteworthy that both in values and in meanings, the teachers of this group are similar in their hedonistic orientation. Therefore, they are extremely focused on getting the maximum pleasure from their profession. This result may explain a slight decrease in positive perceptions of their profession among teachers in today's unstable working conditions in higher education.

We see prospects for further research in the fact that the values and meanings of ideas about the profession of teachers of different generations will be compared. We will compare the results of teachers from different regions of Russia.

\section{Acknowledgements}

The author thanks the scientific supervisor of the project Postnikova M. I. for her help in collecting data for the research.

This work was supported by the RFBR grant Project No. 18-013-00910 "Dynamics of generation values as a marker of transformation of social relations in the Russian society".

\section{Conflict of interests}

The author declare no conflict of interest.

\section{References}

Abakumova, I., Berberyan, A. \& Berberyan, H. (2019). Psychological characteristics of the value orientation system of Armenians in title ethnos and Russian diaspora. International Journal of Cognitive Research in Science, Engineering and Education, 7(2), 11-17. https://doi.org/10.5937/IJCRSEE1902011A

Belousov, K., Erofeeva, E., Erofeeva, T., Leshchenko, Y. \& Zelyanskaya, N. (2015). University Teachers of Linguistics and Self-Image of Their Profession. Procedia - Social and Behavioral Sciences, 214, 667-676. https://doi.org/10.1016/j. sbspro.2015.11.667 
Belova, E. V. (2014). Профрессиональные представления личности как условие успешного профессионального становления [Professional representations of the personality as a condition for successful professional development]. Профрессиональные представления [Professional representation], 1(6), 24-33. (in Russ.) Retrieved from: https:// www.elibrary.ru/item.asp?id=22260538

Chinweuba, A. U., Okoronkwo, I. L., Agbapuonwu, N. E., Garba, S. N. \& Madu, O. T. (2019). Integrated collegiate and professional nursing education in Nigeria universities: Self, task and impact concerns of lecturers. International Journal of Africa Nursing Sciences, 11, Article 100159 https://doi.org/10.1016/j.ijans.2019.100159

Clarà, M. (2014). Understanding teacher knowledge from a Cultural Psychology approach. Teaching and Teacher Education, 43, 110-119. https://doi.org/10.1016/j.tate.2014.07.002

Dart, J., McCall, L., Ash, S., Blair, M. \& Palermo, C. (2019). Toward a Global Definition of Professionalism for Nutrition and Dietetics Education: A Systematic Review of the Literature. Journal of the Academy of Nutrition and Dietetics, 119, 6, 957-971. https://doi.org/10.1016/j.jhlste.2019.100200

Dunning, J. M. (2019). Professional superheroes: Are changes in higher education stretching hospitality management academics' professionalism to the limit? Journal of Hospitality, Leisure, Sport \& Tourism Education, 25, Article 100200. https://doi.org/10.1016/j.jhlste.2019.100200

Duţă, N., Pânişoară, G. \& Pânişoară, I. O. (2014). The Profile of the Teaching Profession - Empirical Reflections on the Development of the Competences of University Teachers . Procedia - Social and Behavioral Sciences, 140, 390-395. https://doi.org/10.1016/j.sbspro.2014.04.440

Erus, S. M., Cakmak, E. \& Celebi, C. D. (2015). Academicians' Perceptions on Their Profession. Procedia - Social and Behavioral Sciences, 186, 33-37. https://doi.org/10.1016/j.sbspro.2015.04.167

Evans, D., Butterworth, G. \& Law, U. (2019). Understanding associations between perceptions of student behaviour, conflict representations in the teacher-student relationship and teachers' emotional experiences. Teaching and Teacher Education, 82, 55-68. https://doi.org/10.1016/j.tate.2019.03.008

Fanggidae, R. E., Suryana,Y., Efendi, N. \& Hilmiana (2016). Effect of a Spirituality Workplace on Organizational Commitment and Job Satisfaction (Study on the Lecturer of Private Universities in the Kupang City -Indonesia). Procedia - Social and Behavioral Sciences, 219(31), 639-646. https://doi.org/10.1016/j.sbspro.2016.05.045

Golyanich, V. M., Bondaruk, A. F., Shapoval, V. A. \& Tulup'eva, T. V. (2018). Ценностные противоречия как психодиагностические критерии профессиональной компетентности и внутриличностного конфликта [Value contradictions as psychodiagnostic criteria of professional competence and intrapersonal conflict]. Экспериментальная психология [Experimental psychology], 11(3), 120-139. (in Russ.) https://doi.org/10.17759/exppsy.2018110309

Karandashev, V. N. (2004). Методика Шварца для изучения ценностей личности: концепция и методическое руководство [The Schwartz method for studying personal values: a concept and methodological guide]. St. Petersburg: Rech, 70. (in Russ.) URL: Retrieved from: http://en.bookfi.net/book/770143

Kekeeva, Z. O. \& Sherayzina, R. M. (2016). Professional formation of the teacher as a source of professional career development. International Journal of Cognitive Research in Science, Engineering and Education, 4(1), 73-78 https:// doi.org/10.5937/IJCRSEE16010730

Koteneva, A. V. \& Kobzarev, S. A. (2019). Особенности ценностно-смысловой сферы спасателей с разным уровнем профессиональной социально-психологической адаптации [Features of the value-semantic sphere of rescuers with different levels of professional socio-psychological adaptation]. Социальная психология и общество [Social psychology and society], 10(1), 35-52. (in Russ.) https://doi.org/10.17759/sps.2019100103

Kotlyakov, V. Yu. (2013). Методика «Система жизненных смыслов» [Technique "System of life meanings"] Becmник Кемеровского государственного университета [Bulletin of Kemerovo State University], 2-1(54), 148-153. (in Russ.) Retrieved from: https://www.elibrary.ru/item.asp?id=19064744\&

Leontiev, A. N. (2005). Деятельность. Сознание. Личность [Activity. Consciousness. Personality]. Moscow: Sense, Academy, 352. (in Russ.) Retrieved from: https://search.rsl.ru/ru/record/01002706567

Lyukshina, D. S. \& Kalita, V. V. (2018). Образ профессии у специалистов особых условий труда приморского края [Image of the profession among specialists of special working conditions of the Primorsky territory]. Психологопедагогические исследования [Psychological and pedagogical research], 10(1), 51-64. (in Russ.) https://doi.org/10.17759/ psyedu.2018100106

Mahipalan, M. \& Sheena, S. (2019). Workplace Spirituality and Subjective Happiness Among High School Teachers: Gratitude As A Moderator. EXPLORE The Journal of Science and Healing, 15(2), 107-114. https://doi.org/10.1016/j. explore.2018.07.002

Moscovici, S. (1990). Social psychology and developmental psychology: extending the conversation. In Duveen G. (eds.), Social representations and development of knowledge. Cambridge: Cambridge University Press, 164-185. https:// doi.org/10.1017/CBO9780511659874.010

Nevgi, A. \& Löfström, E. (2015). The development of academics' teacher identity: Enhancing reflection and task perception through a university teacher development programme. Studies in Educational Evaluation, 46, 53-60. https://doi. org/10.1016/j.stueduc.2015.01.003

Osgood, C. E. (1959). Semantic Space Revisited, Word XV, 1 Google Scholar,: 192-201.

Ovsyannikova, V. V. (1981). Динамика «образа своей профрессии» в зависимости от степени приобщения к ней [Dynamics of the "Image of your profession" depending on the degree of familiarity with it]. Вопросы психологии [Questions of psychology], 5,133-137. (in Russ.) Retrieved from: http://www.voppsy.ru/issues/1981/815/815133.htm

Ovchinnikova, Yu. V., Bogomaz, S. A. \& Gychev, A.V. (2015). Особенности представлений о профрессии у лиц, находящихся на разных этапах профессионального становления. Вестник ТГПУ [TSPUBulletin], 3(156), 28-33. (in Russ.) Retrieved from: https://www.elibrary.ru/item.asp?id=23199545

Panev, V., \& Barakoska, A. (2015). The need of strengthening the pedagogical competences in teaching from the english teachers' perspective. International Journal of Cognitive Research in Science, Engineering and Education, 3(1), 43-50. Retrieved from: http://ijcrsee.com/index.php/ijcrsee/article/view/113

Panov, V. I. \& Selezneva, M. V. (2019). Опыт изучения профессиональных компетенций преподавателей иностранных языков военного вуза на разных стадиях становления субъектности [Experience in studying professional 
Pishchik, V. (2020). Value-semantic bases of ideas about the profession and satisfaction with the profession of higher school teachers, International Journal of Cognitive Research in Science, Engineering and Education (IJCRSEE), 8(2), 69-81

competencies of foreign language teachers at military universities at different stages of subjectivity formation]. Психологическая наука и образование [Psychological science and education], 24(4), 72-80. (in Russ.) https://doi. org/10.17759/pse.2019240406

Peretyatko, L. G. (1991). Профрессиональное призвание личности (психолого-биографичческий аспект): Авторефр. дис. ... канд. психол. наук. [Professional vocation of the individual (psychological and biographical aspect). Ph. D. (Psychology) Thesis]. Moscow, 22. (in Russ.) Retrieved from: https://e-catalog.nlb.by/Record/BY-NLB-rr28040980000

Pryazhnikov, N. S. (2014). Активизирующая профрконсультация. Теория, методы, программы. Методическое пособие [They are consulting. Theory, methods, and programs. Methodical manual]. Moscow: Publ. house "Academy", 460. (in Russ.) Retrieved from: https://www.elibrary.rulitem.asp?id=26548336

Salam, A., Song, C. O., Mazlan, N. F., Hassin, H. \& Abdullah M. H. (2012). A Pilot Study on Professionalism of Future Medical Professionals in Universiti Kebangsaan Malaysia (UKM) Medical Centre. Procedia - Social and Behavioral Sciences, 60, 534-540. https://doi.org/10.1016/j.sbspro.2012.09.419

Sambell, K., Brown, S., \& Graham, L. (2017). Professionalism in practice: Key directions in higher education learning, teaching and assessment. Palgrave Macmillan. Retrieved from: https://www.springer.com/us/book/9783319545516

Schwartz, S. H. (2006). A theory of cultural value orientations: Explication and applications. Comparative Sociology, 5(2-3), 137-182. https://doi.org/10.1163/156913306778667357

Yadov, V. A. \& Kissel, А. А. (1974). Удовлетворенность работой: анализ эмпирических обобщений и попытка их теоретического истолкования [Job Satisfaction: An Analysis of Empirical Generalizations and an Attempt at Their Theoretical Interpretation]. Социологические исследования [Sociological research], 1, 78-88. (in Russ.) Retrieved from: https://search.rsl.ru/ru/record/01007036638 